\title{
MIGRASI TENAGA KERJA DARI SEKTOR PERTANIAN KE NON PERTANIAN DI DESA TATELU KECAMATAN DIMEMBE
}

\author{
Nita Novita Tulangow \\ Nordy F. L. Waney \\ Jean F. J. Timban
}

\begin{abstract}
This study aims to (1) find out the factors that affect the occurrence of labor migration in the village Tatelu, Dimembe Sub-district, North Minahasa Regency, (2) to know the socio-economic background of labor migration from agriculture to non agricultural. (3) to know whether after changing the expectation of labor is realized. This study was conducted from February to April 2016 in Tatelu Village, Dimembe District, North Minahasa Regency. Data collections have used survey method. Techniques of collecting data through interviews used a questionnaire. Sources of data in this study were labor migrants who moved from agriculture to non-agricultural sectors. Secondary data is obtained from Tatelu Village office government. The sampling technique uses purposive sampling. The variables measured in this study were (1) Revenue, (2) Education level, (3) Area of agricultural land, (4) Occupational conditions in non-agricultural, (5) Reasons for labor migration, (7) Number of dependents, (8) Social activities that are usually followed by labor in the village. Data Analysis Method used Primary data obtained is processed descriptively. The results showed (1) the factors that encourage the migration of labor from agriculture to non-agriculture namely; reduced agricultural land, low wages in agriculture, age, and non-farm employment are more promising, (2) Most of the respondents who follow social activities in the village of Tatelu such as harmonious because in addition to beneficial for the respondent can also strengthen the rope fraternity among members of the rukun. By participating in the rukun in the village, the respondent must have more income because they have to spend money in every meeting that is always held. (3) After migrating from agriculture to non-agricultural sector, all expectation of interviewed respondents is realized because besides earning big enough they also feel comfortable working in non-agricultural sector.
\end{abstract}

Keywords: Migration, labor, agriculture, non-agriculture, Tatelu Village, Dimembe Sub-district, North Minahasa District

\section{ABSTRAK}

Penelitian ini bertujuan untuk mengetahui (1) faktor-faktor yang mempengaruhi terjadinya migrasi tenaga kerja di Desa Tatelu Kecamatan Dimembe, (2) latar belakang sosial ekonomi dari tenaga kerja yang berpindah dari sektor pertanian ke non pertanian. (3) apakah setelah berpindah harapan tenaga kerja tersebut terwujud. Penelitian ini dilakukan dari bulan Februari sampai April 2016 di Desa Tatelu, Kecamatan Dimembe, Kabupaten Minahasa Utara. Pengumpulan data menggunakan metode survey. Teknik pengumpulan data melalui wawancara dengan menggunakan kuesioner. Sumber data dalam penelitian ini adalah responden tenaga kerja yang berpindah dari sektor pertanian ke non-pertanian. Data sekunder diperoleh, antara lain, dari pemerintah Desa Tatelu. Teknik sampling menggunakan Purpossive Sampling. Variabel yang diukur dalam penelitian ini adalah (1) Pendapatan, (2) Tingkat pendidikan, (3) Luas lahan pertanian, (4) Kondisi pekerjaan di non-pertanian, (5) Alasan migrasi tenaga kerja, (7) Jumlah tanggungan, (8) Aktivitas sosial yang biasanya diikuti tenaga kerja di desa. Metode Analisis Data menggunakan Data primer yang diperoleh diolah secara deskriptif. Hasil penelitian menunjukkan (1) faktor-faktor yang mendorong terjadinya migrasi tenaga kerja dari sektor pertanian ke non-pertanian yaitu; berkurangnya lahan pertanian, upah di sektor pertanian yang rendah, faktor usia, dan pekerjaan di sektor non-pertanian lebih menjanjikan, (2) Sebagian besar responden yang mengikuti kegiatan sosial di Desa Tatelu seperti rukun dikarenakan selain menguntungkan bagi responden juga dapat mempererat tali persaudaraan antar sesama anggota rukun tersebut. Dengan mengikuti rukun di desa, responden harus memiliki pendapatan yang lebih dikarenakan harus mengeluarkan dana dalam setiap pertemuan yang selalu diadakan. (3) Setelah berpindah pekerjaan dari sektor pertanian ke non-pertanian, semua harapan responden yang diwawancarai terwujud karena selain penghasilan yang didapat cukup besar mereka juga merasa nyaman bekerja di sektor non pertanian.

Kata kunci : Migrasi, tenaga kerja, sektor pertanian, non pertanian, Desa Tatelu, Kecamatan Dimembe, Kabupaten Minahasa Utara 


\section{PENDAHULUAN}

\section{Latar Belakang}

Kecenderungan migrasi tenaga kerja dari sektor pertanian ke sektor non pertanian dialami oleh semua negara berkembang, termasuk Indonesia. Di satu sisi, negaranegara bekembang harus mempercepat laju pembangunan di sektor pertanian juga untuk mendukung kemajuan sektor industri. Dengan banyaknya migrasi tenaga kerja dari sektor pertanian ke sektor non pertanian akan memperburuk perkembangan sektor pertanian karena sektor ini akan kekurangan tenaga kerja sehingga biaya produksi pertanian menjadi semakin mahal. Kemajuan ilmu pengetahuan menyebabkan sektor pertanian lebih banyak bersifat padat modal daripada padat karya. Ini artinya penyerapan tenaga kerja di sektor pertanian menjadi lebih sedikit dan digantikan oleh teknologi yang lebih bersifat padat modal. Pada gilirannya akan memacu tenaga kerja di sektor pertanian bekerja ke sektor non pertanian (Arief dalam Sumanto, 2009). Ledakan penduduk di negara berkembang semakin mempertinggi kemungkinan beralihnya tenaga kerja. Sebagai kelanjutannya, sektor informal semakin berkembang di daerah-pertanian. Banyak bermunculan industri-industri di daerah berbasis pertanian, baik industri besar, sedang, kecil maupun industri rumah tangga yang beragam. Apalagi di dalam situasi kelesuan ekonomi, ternyata sektor-sektor informal lebih banyak memberikan daya tahan hidup untuk menampung ledakan penduduk yang masuk pasar kerja sementara menunggu kegiatan ekonomi pulih kembali (Simanjuntak dalam Sumanto, 2009). Sektor pertanian awalnya merupakan sektor yang diandalkan bagi perkembangan perekonomian Desa Tatelu seiring berjalannya waktu dan pengembangan pembangunan juga dampak dari modernisasi, sektor pertanian mengalami penurunan dan perkembangan sektor non pertanian mengalami kemajuan khususnya sektor industri, dan juga sampai saat ini terus mengalamai peningkatan. Pembangunan industri meliputi industri primer (pertambangan), industri sekunder (konstruksi dan manufaktur), serta industri tersier (transportasi, komunikasi dan sektor jasa lainnya).

Data pemerintah Desa Tatelu pada tahun 2015/2016, menunjukan jumlah luas lahan pertanian adalah 1,147.05 hektar sedangkan luas lahan non pertanian 72.92 hektar, hal ini berarti walaupun sektor non pertanian semakin meningkat, lahan pertanian masih cenderung melimpah. Peneliti ingin mencari tahu dengan adanya lahan yang melimpah tersebut mengapa para pekerja beralih ke sektor non pertanian.

\section{Rumusan Masalah}

Rumusan masalah dalam penelitian ini adalah

1. Faktor-faktor apa yang mendorong terjadinya migrasi tenaga kerja di Desa Tatelu Kec. Dimembe?

2. Bagaimana latar belakang sosial ekonomi tenaga kerja yang berpindah dari sektor pertanian ke sektor non pertanian?

3. Apakah setelah berpindah harapan tenaga kerja tersebut terwujud?

\section{Tujuan Penelitian}

adalah:

Tujuan dalam penelitian ini

1. Untuk mengetahui faktor-faktor yang mempengaruhi terjadinya migrasi tenaga kerja di Desa Tatelu Kec.Dimembe.

2. Untuk mengetahui latar belakang sosial ekonomi dari tenaga kerja yang berpindah dari sektor pertanian ke non pertanian.

3. Untuk mengetahui apakah setelah berpindah harapan tenaga kerja tersebut terwujud.

\section{Manfaat Penelitian}

Manfaat dari penelitian ini adalah

1. Penelitian ini menyediakan informasi terkini mengenai Migrasi Tenaga Kerja di Desa Tatelu Kec. Dimembe. 
2. Penelitian ini terdapat informasi mengenai faktor apa yang mendorong terjadinya migrasi tenaga kerja serta diberikan informasi mengenai latar belakang sosial ekonomi dari teneaga kerja yang berpindah dari sektor pertanian ke sektor non pertanian dan apakah setelah berpindah harapan tenaga kerja tersebut terwujud atau tidak.

3. Penelitian ini diharapkan dapat memberikan infomasi yang penting untuk perkembangan Desa.

\section{METODOLOGI PENELITIAN}

\section{Waktu dan Tempat Penelitian}

Penelitian ini dilakukan selama tiga bulan yaitu bulan Februari sampai April 2016. Lokasi yang dijadikan tempat penelitian adalah Desa Tatelu Kecamatan Dimembe Kabupaten Minahasa Utara. Pemilihan lokasi ini berdasarkan kondisi desa yang cukup strategis dimana pertambangan dan budidaya ikan yang cukup berkembang sehingga berpotensi bagi warga setempat untuk melakukan migrasi dari sektor pertanian ke non-pertanian.

\section{Metode Pengumpulan Data}

Pengumpulan data menggunakan metode survey. Teknik pengumpulan data melalui wawancara dengan menggunakan kuisioner. Sumber data dalam penelitian ini adalah responden tenaga kerja yang berpindah dari sektor pertanian ke non-pertanian. Data sekunder diperoleh dari pemerintah desa tatelu dan sumber-sumber lainya.

\section{Metode Pengambilan}

Populasi dalam penelitian ini berjumlah 50 orang dan sampel dalam penelitian ini adalah Tenaga Kerja Desa Tatelu Kec. Dimembe yang telah berpindah dari sektor pertanian ke non pertanian. Teknik sampling menggunakan Purpossive Sampling. Yaitu teknik pengambilan sampel untuk tujuan tertentu. "Purposive sampling" bertujuan untuk memperoleh informasi dan data dari tenaga kerja yang telah berpindah dari sektor pertanian ke non pertanian didesa tatelu. Pengambilan sampel hanya dilakukan pada pihak-pihak yang bersedia di mintai informasi.

Penentuan sampel didasarkan pada kebutuhan penelitian yaitu terhadap tenaga kerja Desa Tatelu Kecamatan Dimembe yang melakukan migrasi tenaga kerja dari sektor pertanian ke non-pertanian dalam jangka waktu 5 tahun terakhir. Jumlah sampel yang akan diwawancara 20 orang.

\section{Konsep Pengukuran Variabel}

1. Pendapatan adalah pendapatan responden pada per masapanen saat bekerja di sektor pertanian dan setelah berpindah pekerjaan di luar sektor pertanian

a. Pendapatan responden di sektor pertanian dihitung berdasarkan data pendapatan dari usaha tani tang diusahakan dan dihitung per masapanen.

b. Pendapatan di luar sektor pertanian dihitung berdasarkan penghasilan yang diterima responden dari usaha atau pekerjaan tersebut.

2. Tingkat pendidikan yaitu jenjang pendidikan formal tertinggi yang dicapai responden

3. Luas lahan pertanian : adalah luas lahan yang dimiliki/dikuasai dan diusahakan oleh responden sebelum berpindah di sektor non pertanian.

4. Kondisi pekerjaan di non-pertanian : suasana kerja yang dialami dan dihadapi oleh resonden yang bekerja pada 1 pekerjaan tertentu diluar sektor pertanian

5. Alasan migrasi tenaga kerja: alasan tenaga kerja beralih pekerjaan dari pertanian ke non pertanian

6. Jumlah tanggungan : jumlah tanggungan responden dalam rumah tangga

7. Aktivitas sosial yang biasanya diikuti tenaga kerja di desa. 


\section{Metode Analisis Data}

Data primer yang diperoleh diolah secara deskriptif. Faktor-faktor terjadinya Migrasi tenaga kerja dari sektor pertanian ke non pertanian di ambil dari data latar belakang sosial ekonomi tenaga kerja yang berpindah dari sektor pertanian ke sektor non pertanian. Data disajikan secara tabelaris kemudian diuraikan secara deskrptif.

\section{HASIL DAN PEMBAHASAN}

\section{Gambaran Umum Objek Penelitian}

\section{Kondisi Geografis}

\section{Batas Wilayah}

Desa Tatelu merupakan salah satu Desa di Wilayah Kecamatann Dimembe, yang terletak di Kabupaten Minahasa Utara, Ketinggian dari dasar laut 450 sampai 600 meter, Dengan suhu rata-rata 20 sampai dengan 29 derajat celcius, Curah hujan tidak menentu. Batas Wilayah Desa Tatelu dengan :

> Terletak di Bujur Lintang Utara 71600 72600

$>$ Terletak di Bujur Timur 17500

\section{Topografi Datar}

Kesuburan tanah yang menghasilkan berbagai komoditi unggulan seperti Kelapa, Padi, Jagung, Cengkih, Pala. Buah-buahan Pepaya, Pisang dan tanaman ubi-ubian lainnya serta hasil pertambangan emas

\section{Luas Wilayah}

Desa Tatelu adalah salah satu Desa di Wilayah Kecamatan Dimembe dengan jumlah jaga 6 jaga dengan luas wilayah : 1.217,98 Ha. Terdiri dari : Perkampungan 32,65 Ha, Ladang/Kebun 778 Ha, Sawah 214 Ha, Kolam 65 Ha, Hutan 90,05 Ha, dan Tambang Emas $27 \mathrm{Ha}$.

\section{Orbitasi}

Jarak Desa Tatelu dengan:

$>$ Jumlah penduduk desa 5 tahun sebelum dan saat ini
$>$ Pertumbuhan penduduk selama 5 tahun

$>$ Penduduk menurut lapangan pekerjaan

$>$ Penduduk menurut pendidikan formal

$>$ Penduduk menurut kesehatan

$>$ Pemerintah Provinsi Sulawesi Utara (Kota Manado) : $\pm 25 \mathrm{KM}$.

$>$ Pemerintah Kabupaten Minahasa Utara (Kota Airmadidi) : $\pm 11 \mathrm{KM}$.

$>$ Pemerintah Kecamatan Dimembe (Kantor Camat) : $\pm 4 \mathrm{KM}$.

\section{Topografi Datar}

Berikut pada Tabel 1 adalah data jumlah penduduk menurut jenis kelamin di Desa Tatelu s/d Desember 2016:

\section{Luas Wilayah}

Desa Tatelu adalah salah satu Desa di Wilayah Kecamatan Dimembe dengan jumlah jaga 6 jaga dengan luas wilayah : 1.217,98 $\mathrm{Ha}$. Terdiri dari : Perkampungan 32,65 Ha, Ladang/Kebun 778 Ha, Sawah 214 Ha, Kolam 65 Ha, Hutan 90,05 Ha, dan Tambang Emas $27 \mathrm{Ha}$.

\section{Orbitasi}

Jarak Desa Tatelu dengan:

$>$ Jumlah penduduk desa 5 tahun sebelum dan saat ini

$>$ Pertumbuhan penduduk selama 5 tahun

$>$ Penduduk menurut lapangan pekerjaan

$>$ Penduduk menurut pendidikan formal

$>$ Penduduk menurut kesehatan

$>$ Pemerintah Provinsi Sulawesi Utara (Kota Manado) : $\pm 25 \mathrm{KM}$.

$>$ Pemerintah Kabupaten Minahasa Utara (Kota Airmadidi) : $\pm 11 \mathrm{KM}$.

$>$ Pemerintah Kecamatan Dimembe (Kantor Camat) : $\pm 4 \mathrm{KM}$.

\section{Kondisi Demografi}

Berikut pada Tabel 1 adalah data jumlah penduduk menurut jenis kelamin di Desa Tatelu s/d Desember 2016:

Tabel 1. Jumlah Penduduk S/d Desember 2016

\begin{tabular}{cccc}
\hline \multirow{2}{*}{ Jaga } & \multicolumn{2}{c}{ Jenis Kelamin } & \multirow{2}{*}{ Jumlah } \\
\hline I & 311 & 276 & 587 \\
II & 234 & 230 & 464 \\
III & 400 & 402 & 802 \\
IV & 253 & 242 & 495 \\
V & 257 & 227 & 484 \\
VI & 257 & 274 & 531 \\
\hline Jumlah & 1.712 & 1.651 & 3.363 \\
\hline Sumber : Diolah dari data sekunder, 2016
\end{tabular}




\section{Karakteristik Responden}

\section{Jenis Kelamin}

Jenis kelamin adalah perbedaan bentuk, sifat, dan fungsi biologi laki-laki dan perempuan yang menentukan perbedaan peran mereka dalam menyelenggarakan upaya meneruskan garis keturunan. Perbedaan ini terjadi karena mereka memiliki alat-alat untuk meneruskan keturunan yang berbeda, yang disebut alat reproduksi. Jenis kelamin adalah perbedaan antara wanita dengan pria secara biologis sejak seseorang lahir. Perbedaan jenis kelamin biasanya berpengaruh pada perbedaan tugas pekerjaan, pria cenderung memiliki pekerjaan yang lebih berat dibandingkan dengan pekerjaan wanita. Jumlah tenaga kerja laki-laki di sektor pertanian cenderung lebih banyak di bandingkan dengan tenaga kerja wanita karena peran pria paling dominan untuk bekerja di sektor pertanian. Hal ini disebabkan karena pekerjaan perempuan hanya pekerjaan yang lebih ringan dari pria. Dari 20 responden, ada (16) Pria dan (4) Wanita, dapat dilihat pada Tabel 2.

Tabel 2. Jenis Kelamin Responden

\begin{tabular}{ccc}
\hline Jenis Kelamin & $\begin{array}{c}\text { Jumlah } \\
\text { (Responden) }\end{array}$ & $\begin{array}{c}\text { Presentase } \\
(\boldsymbol{\%})\end{array}$ \\
\hline Pria & 16 & 80 \\
Wanita & 4 & 20 \\
\hline Jumlah & 20 & 100 \\
\hline Sumber : Data Primer 2016 &
\end{tabular}

\section{Umur}

Umur adalah lamanya hidup dalam tahun yang dihitung sejak dilahirkan. Dalam Tabel 3 terdapat umur responden yang telah beralih pekerjaan dari sektor pertanian ke non pertanian.

\section{Tabel 3. Umur Responden}

\begin{tabular}{cccc}
\hline No. & $\begin{array}{c}\text { Umur } \\
\text { (Tahun) }\end{array}$ & $\begin{array}{c}\text { Jumlah } \\
\text { (Responden) }\end{array}$ & $\begin{array}{c}\text { Presentase } \\
(\boldsymbol{\%})\end{array}$ \\
\hline 1. & $20-30$ & 3 & 15 \\
2. & $31-40$ & 6 & 30 \\
3. & $41-50$ & 2 & 10 \\
4. & $51>$ & 9 & 45 \\
\hline \multicolumn{2}{c}{ Jumlah } & 20 & 100 \\
\hline
\end{tabular}

Sumber : Data Primer 2016

Umur berpengaruh nyata terhadap besarnya kesempatan kerja. Semakin tua umur seorang tenaga kerja maka akan semakin rendah kesempatan kerjanya. Umur tersebut digolongkan menjadi belum produktif $(0-14)$, produktif (15-64), dan tidak produktif (65-75 secara keseluruhan, masyarakat yang melakukan migrasi berada pada usia produktif, artinya secara umum sudah mampu untuk melakukan suatu pekerjaan. Mayoritas responden berusia 50 sampai 51 tahan keatas dengan persentase ( 9 orang). Berdasarkan Tabel 3 dalam penyajian data, umur di bagi menjadi 4 kategori yaitu umur 20-30 tahun, 31-40 tahun, 41-50 tahun, dan lebih dari 51 tahun. Dari 20 responden diperoleh data umur, yang terbanyak umur (51>) yaitu 9 orang, kemudian umur (31 sampai 40) 6 orang, umur (20 sampai 30) 3 orang, dan umur (41-50) 2 orang.

\section{Pendidikan Terakhir}

Pendidikan juga berpengaruh pada tingkat pekerjaan dari seseorang. Dalam Tabel 4 semakin tinggi pendidikan semakin luas kesempatan untuk bekerja.

Tabel 4. Pendidikan Terakhir Responden

\begin{tabular}{cccc}
\hline No & $\begin{array}{c}\text { Pendidika } \\
\text { n Terakhir }\end{array}$ & $\begin{array}{c}\text { Jumlah } \\
\text { (Responden }\end{array}$ & $\begin{array}{c}\text { Presentas } \\
\text { e (\%) }\end{array}$ \\
1. & SD & 5 & \\
2. & SMP & 6 & 25 \\
3. & SMA & 9 & 30 \\
\hline Jumlah & & 20 & 100 \\
\hline
\end{tabular}

Sumber :data Primer 2016

Pendidikan terakhir responden umumnya beragam, mulai dari SD hingga SMA. Responden yang beralih pekerjaan berdasarkan pendidikan dapat digolongkan menjadi 3 kelompok yaitu SD, SMP hingga SMA. Pendidikan terakhir tidak berpengaruh pada responden untuk bekerja di sektor pertanian maupun saat beralih pekerjaan. Karna pekerjaan di sektor pertanian tidah harus memiliki pendidikan yang tinggi. Gambaran mengenai tingkatan pendididkan responden dapat dilihat dalam Tabel 4.

\section{Pekerjaan Utama}

Pekerjaan utama yang dilakukan orang untuk memenuhi kebutuhannya Setiap hari. Tenaga kerja mempunyai kebutuhan pokok yang harus dipenuhi. kebutuhan yang harus segera di penuhi dan tidak bisa ditunda, misalnya makan, minum, pakaian, membeli 
alat-alat kebutuhan sekolah dan sebagainya, untuk memperoleh semua kebutuhan tersebut diperlukan uang. Dalam Tabel 5 terdapat pekerjaan utama para responden sesudah beralih pekerjaan dari sektor pertanian ke non pertanian.

\section{Tabel 5. Pekerjaan Utama Responden}

\begin{tabular}{|c|c|c|c|}
\hline $\begin{array}{c}\text { No } \\
\text {. }\end{array}$ & $\begin{array}{l}\text { Pendidika } \\
\text { n Terakhir }\end{array}$ & $\begin{array}{c}\text { Jumlah } \\
\text { (Responden } \\
\text { ) }\end{array}$ & $\begin{array}{c}\text { Presentas } \\
\text { e (\%) }\end{array}$ \\
\hline 1. & Penambang & 8 & 40 \\
\hline 2. & $\begin{array}{l}\text { Tukang } \\
\text { Ojek }\end{array}$ & 3 & 15 \\
\hline 3. & $\begin{array}{c}\text { Buruh } \\
\text { Bangunan }\end{array}$ & 1 & 5 \\
\hline 4. & $\begin{array}{l}\text { Pegawai } \\
\text { Indomaret }\end{array}$ & 1 & 5 \\
\hline 5. & Wirausaha & 4 & 20 \\
\hline 6. & Sopir & 3 & 15 \\
\hline Jum & & 20 & 100 \\
\hline
\end{tabular}

Sumber : Data Primer 2016

Pekerjaan utama responden yang telah beralih bervariasi mulai dari penambang, tukang ojek, buruh bangunan, pegawai indomaret, wirausaha. Jenis pekerjaan responden setelah beralih dapat dilihat dari Tabel 5. Dapat dilihat dari gambar diatas profesi yang banyak digeluti oleh responden adalah bekerja sebagai penambang sebanyak 8 orang. Responden kebanyakan beralih pekerjaan ke penambang dikarenakan di Desa Tatelu Kecamatan Dimembe memiliki lahan pertambangan yang lebih menanjikan hasilnya dibandingkan di sektor pertanian. Responden yang berwirausaha sebanyak 4 orang alasan responden memilih berwirausaha dikarenakan mereka suka berinovasi dan memiliki modal untuk berwirausaha. Berdasarkan 20 orang responden, 3 orang diantaranya yang berprofesi sebagai tukang ojek adalah responden yang berumur 51 tahun keatas. Mereka memilih profesi ini karena pendapatan yang diterima jauh lebih menguntungkan dibanding berprofesi sebagai tenaga kerja disektor pertanian dan menganggap bahwa pekerjaan tidak membutuhkan tenaga besar, pekerjaan lebih ringan dibanding sebagai petani. Adapun responden yang beralih profesi sebagai supir angkot sebanyak 3 orang yang berumur 51 tahun keatas. Responden yang tersisa 2 orang ada yang 1 orang berprofesi sebagai buruh bangunan dan satunya lagi sebagai karyawan indomaret.

\section{Pekerjaan Sampingan}

Pekerjaan sampingan oleh responden seperti usaha atau pekerjaan yang dikerjakan oleh di luar pekerjaan aslinya yang selama ini telah digeluti dan di kerjakan. Responden yang diwawancarai ada juga yang mempunyai pekerjaan sampingan. Tujuan adanya pekerjaan sampingan dikarenakan pekerjaan utama dari responden tidak mencukupi dalam kehidupan sehari-hari. Data mengenai pekerjaan sampingan terdapat dalam Tabel 6 .

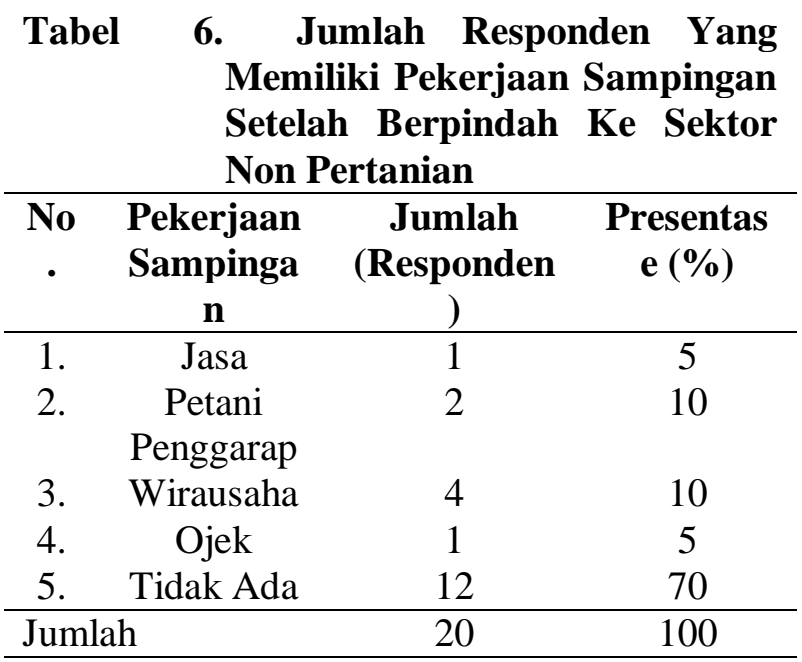

Sumber : Data Primer 2016

Berdasarkan 20 orang responden, 6 orang dianataranya mempunyai pekerjaan sampingan agar memiliki pendapatan tambahan. Adapun pekerjaan sampingan yang mereka tekuni seperti pekerja dibidang jasa, petani penggarap, wirausaha, dan tukang ojek. Dari 20 responden yang diwawancarai, ada 8 rosponden yang memiliki pekerjaan sampingan. 2 responden sebagai petani penggarap, 4 responden sebagai wirausaha, 1 responden tukang ojek dan 1 responden bekerja dibidang jasa yaitu bekerja sesuai keahlianya sebagai tukang gunting rambut dan sebagai tukang ledeng. Ada 2 responden yang tidak beralih sepenuhnya karena masih bekerja di sektor non pertanian meski hanya sebagai pekerjaan sampingan, alasanya karena biaya hidup tidak mencukupi. 


\section{Jumlah Tanggungan Responden}

Jumlah tanggungan responden akan berpengaruh pada motivasi kerja, baik dalam hal memilih pekerjaan maupun lama kerja yang akan dijalani. Dalam Tabel 7 terdapat jumlah tanggungan dari 20 responden yang telah berpindah dari sektor pertanian ke non pertanian.

\begin{tabular}{|c|c|c|c|}
\hline No. & $\begin{array}{c}\text { Jumlah } \\
\text { Tanggungan }\end{array}$ & Responden & $\begin{array}{c}\text { Presentase } \\
(\%)\end{array}$ \\
\hline 1. & 1 & 7 & 35 \\
\hline 2. & 27 & 3 & 5 \\
\hline 3. & 3 & 3 & 15 \\
\hline 4. & 5 & 1 & 5 \\
\hline 5. & Tidak Ada & 2 & 10 \\
\hline Juml & & 20 & 100 \\
\hline
\end{tabular}

Sumber : Data Primer 2016

Anggota keluarga adalah anggota dalam rumah tangga yang termasuk satuan unit anggaran satu dapur, termasuk anak sekolah yang tinggal serumah dan menjadi tanggungan keluarga, tetapi tidak termasuk orang lain yang tinggal serumah yang tidak ikut makan dalam rumah tersebut. Umumnya beban tanggungan keluarga terdiri dari 3-4 orang, yang meliputi suami, istri dan anak. Berdasarkan Tabel 7, dari 20 orang responden semuanya memiliki tanggungan. 7 orang responden masing-masing memiliki jumlah tanggungan sebanyak 2 orang, sedangkan 1 responden memiliki 5 orang tanggungan, dan 2 diantaranya tidak memiliki tanggungan.

\section{Jumlah Responden Menurut Tipe Pekerja}

Responden yang telah berpindah memiliki tipenya masing-masing sehingga berpengaruh pada pemilihan pekerjaan ketika berpindah. Dalam Tabel 8 terdapat tipe pekerja, baik yang disebut avonturir maupun pekerja keras.

\section{Tabel 8. Tipe Pekerja}

\begin{tabular}{lccc}
\hline No. & $\begin{array}{c}\text { Tipe } \\
\text { Pekerja }\end{array}$ & $\begin{array}{c}\text { Jumlah } \\
\text { (Responden) }\end{array}$ & $\begin{array}{c}\text { Presentase } \\
(\mathbf{\%})\end{array}$ \\
\hline $1 . \quad \begin{array}{c}\text { Pekerja } \\
\text { Keras }\end{array}$ & 13 & 65 \\
2. & Avonturir & 7 & 35 \\
\hline Jumlah & 20 & 100 \\
\hline \multicolumn{2}{l}{ Sumber : Data Primer 2016}
\end{tabular}

Tabel 8 menunjukan bahwa ada 2 tipe pekerja yang ditemui dalam penelitian ini yaitu pekerja keras dan pekerja yang disebut avonturir. Pekerja keras adalah pekerja yang Pantang menyerah, selain mencintai pekerjaanya pekerja keras tidak mudah menyerah dan putus asa menghadapi suatu pekerjaan, seberat apapun pekerjaanya. Oleh karena itu, sebelum pekerjaan itu selesai dan memperoleh hasil yang memuaskan, tidak akan menyerah dan putus asa tapi tetap berusaha. pekerjaan yang dihadapi dapat diselesaikan dengan baik, Disiplin dan selalu menyelesaikan pekerjaan tepat waktu. Sedangkan pekerja avonturir mereke yang suka berpindah pekerjaan yang tidak puas dengan pekerjaan yang didapat. Seseorang yang memiliki jiwa dan sikap wirausaha selalu tidak puas dengan apa yang telah dicapainya. Dari waktu ke waktu, seorang wirausaha selalu meningkatkan usahanya. Ia selalu berkreasi tanpa henti. Berdasarkan Tabel 8 dari 20 responden terdapat 7 responden yang disebut pekerja keras dan 13 responden suka avonturir.

\section{Lama Tinggal di Desa Tatelu}

Responden yang telah berpindah pekerjaan berbeda-beda lamanya tinggal Di Desa Tatelu Kecamatan Dimembe. Terbukti dari Tabel 9 responden yang berpindah bervariasi mulai dari 5 tahun sampai 20 tahun, 21 tahun sampai 35 tahun, 36 tahun sampai 50 tahun dan 51 tahun sampai 70 tahun.

\begin{tabular}{|cccc} 
Tabel & 9. Lama Tinggal di Desa Tatelu & \\
\hline No. & Lama Tinggal & $\begin{array}{c}\text { Jumlah } \\
\text { (Responden) }\end{array}$ & Presentase (\%) \\
\hline 1. & $5-20$ & 6 & 30 \\
2. & $21-35$ & 2 & 10 \\
3. & $36-50$ & 5 & 25 \\
4. & $51-70$ & 7 & 35 \\
\hline Jumlah & & 20 & 100 \\
\hline
\end{tabular}

Sumber : Data Primer 2016

Tabel 9 menunjukan bahwa dari 20 orang responden yang ada 6 orang responden diantaranya tinggal di Desa Tetelu berkisar 5-20 tahun, 21-35 tahun ada 2 orang dan di 36-50 tahun ada 5 orang sedangkan di 51-70 tahun sebanyak 7 orang. Perpindahan tenaga kerja diikur dari 5 sampai 10 tahun sehingga lamanya tinggal di Desa Tatelu juga berpengaruh pada responden yang berpindah pekerjaan.

\section{Status Petani}

Responden yang berpindah pekerjaan ke sektor pertanian tidak semua memiliki lahan sendiri untuk digarap. Biasanya yang mempunyai lahan sendiri ialah mereka yang dulunya tidak hanya bekerja di sektor pertanian, juga sebagai pemilik. Responden yang dulunya hanya sebagai penggarap saja biasanya hanya menggarap lahan milik orang lain. Dalam Tabel 10 berisi tentang jumlah responden, kepemilikan lahan serta pekerjaan di sektor pertanian. 
Tabel 10. Jumlah Responden Menurut Status Petani Sebelum Beralih Pekerjaan

\begin{tabular}{lccc}
\hline No. & Status petani & $\begin{array}{c}\text { Jumlah } \\
\text { (Responden) }\end{array}$ & Presentase (\%) \\
\hline 1. & $\begin{array}{c}\text { Pemilik dan } \\
\text { Penggarap }\end{array}$ & 9 & 45 \\
2. & Penggarap & 11 & 55 \\
\hline Jumlah & & 20 & 100 \\
\hline \multicolumn{2}{l}{ Sumber : Data Primer 2016 }
\end{tabular}

Berdasarkan Tabel 10 dapat dilihat bahwa tidak semua responden memiliki lahan sendiri untuk diolah. Dari 20 responden Ada 9 responden yang menjadi pemilik serta menggarap lahanya sendiri berjumlah 9 orang, yang menjadi penggarap ada 8 orang, sedangkan sisanya sebagai petani penggarap berjumlah 3 orang responden.

\section{Luas Lahan yang Dimiliki Sebelum Beralih ke Non Pertanian}

Desa Tatelu adalah salah satu Desa di Wilayah Kecamatan Dimembe dengan jumlah 6 jaga dengan luas wilayah : 1.217,98 Hektar Sedangkan Ladang/Kebun 778 Hektar.

Tabel 11. Jenis Lahan dan Luas Lahan yang Dimiliki/ Dikuasai

\begin{tabular}{|c|c|c|c|c|}
\hline \multicolumn{5}{|c|}{ Responden Sebelum Beralih ke Non Pertanian } \\
\hline No & Jenis Lahan & Responden & $\begin{array}{c}\text { Luas } \\
\text { Lahan } \\
\text { (Ha) }\end{array}$ & $\begin{array}{c}\text { Presentase } \\
(\%)\end{array}$ \\
\hline 1. & $\begin{array}{l}\text { Lahan } \\
\text { Kering }\end{array}$ & 3 & 1 & 13,33 \\
\hline 2. & $\begin{array}{l}\text { Lahan } \\
\text { Kering }\end{array}$ & 3 & 1,5 & 20,00 \\
\hline 3. & $\begin{array}{l}\text { Lahan } \\
\text { Kering }\end{array}$ & 2 & 2 & 26,67 \\
\hline 4. & $\begin{array}{l}\text { Lahan } \\
\text { Kering }\end{array}$ & 3 & 3 & 40,00 \\
\hline 5. & Tidak Ada & 8 & 0 & 0,00 \\
\hline Total & & 20 & 7,5 & 100 \\
\hline$\overline{R a t a-1}$ & & & 1,875 & \\
\hline
\end{tabular}

Sumber : Data Primer 2016

'Dari Tabel 11 dapat dilihat bahwa 8 orang responden tidak memiliki lahan sendiri seperti yang berprofesi sebagai penggarap yang hanya menggarap lahan milik orang lain tanpa memiliki lahan sendiri. Ada 3 responden yang memiliki lahan kering dan masing-masing luas tanahnya 1 hektar, 3 responden yang memiliki luas lahan seluas 1,5 hektar berupa lahan kering, 2 reponden memiliki luas lahan seluas 2 hektar, sedangkan 3 responden lainya memiliki luas lahan masing-masing 3 hektar. Semua responden yang ada hanya memiliki lahan kering saja dikarenakan menurut responden lahan kering lebih menguntungkan karena banyak kegunaanya, seperti memanam pepaya, jagung, pisang, rempah-rempah, selain itu ada juga yang memelihara ikan (dalam telaga).

\section{Jenis Tanaman yang di Panen}

Jenis tanaman yang ada di Desa Tatelu Kecamatan Dimembe terdapat beberapa jenis tanaman seperti: jagung, kelapa, pepaya, ubi jalar dan pala. Dalam Tabel 12 terdapat jenis-jenis tanaman, harga per kilogram, dan masa panennya. Ada 3 responden yang menanan jagung dengan harga per kilogram Rp.5.000 dan masa panen berkisar 2 sampai 3 bulan. Sedangkan responden yang menanam kelapa berjumlah 6 orang dengan harga Rp.6.000 per kilogram dan masa panen berkisaran 2 sampai 3 bulan. Namun dibandingkan pepaya masa panennya lebih lama berkisar 3 sampai 4 bulan dengan harga per kilonya Rp.2.500. Selain itu ada 3 responden yang menanam ubi-ubian dengan harga Rp.1.400 per kilogram dan masa panennya 3 bulan. Pala juga menjadi salah satu jenis tanaman yang dipanen oleh 5 responden dengan harga Rp.1.700 dan masa panen terlama berkisar 6 sampai 7 bulan.

Tabel 12. Jenis Tanaman, Masa Panen dan Harga Jual yang Dimiliki/ Dikuasai Responden

\begin{tabular}{cccc}
\hline $\begin{array}{c}\text { Jumlah } \\
\text { (Responden) }\end{array}$ & $\begin{array}{c}\text { Jenis } \\
\text { Tanaman }\end{array}$ & $\begin{array}{c}\text { Masa } \\
\text { Panen } \\
\text { (Bulan) }\end{array}$ & $\begin{array}{c}\text { Harga Jual } \\
\text { (Kg) }\end{array}$ \\
\hline 3 & Jagung & $2-3$ & 5.000 \\
6 & Kelapa & $2-3$ & 6.000 \\
3 & Pepaya & $3-4$ & 2.500 \\
3 & Ubi & 3 & 1.400 \\
5 & Pala & $6-7$ & 1.700 \\
\hline Sumber $:$ Data Primer 2016 & &
\end{tabular}

Sumber : Data Primer 2016

\section{Pendapatan Usahatani}

Pendapatan usaha tani tiap panen berpengaruh pada alasan kenapa responden berpindah dari sektor pertanian ke non pertanian. Kurangnya pendapatan ketika bekerja di non pertanian menjadi salah satu penyebab terbesar responden berpindah pekerjaan ke sektor non pertanian. Dalam Tabel 13 terdapat pendapatan responden ketika masih bekerja disektor non pertanian.

\begin{tabular}{ccc} 
Tabel 13. Pendapatan Responden Per Masa Panen \\
\hline $\begin{array}{c}\text { Pendapatan per masa } \\
\text { Panen }\end{array}$ & $\begin{array}{c}\text { Jumlah } \\
\text { (Responden) }\end{array}$ & $\begin{array}{c}\text { Presentase } \\
(\%)\end{array}$ \\
\hline$>500.000$ & 1 & 5 \\
$500.000-1.000 .000$ & 16 & 80 \\
$1.000 .001-2.000 .000$ & 1 & 5 \\
$>2.000 .000$ & 2 & 10 \\
\hline Jumlah & 20 & 100 \\
\hline
\end{tabular}

Sumber : Data Primer 2016

Responden yang dulunya bekerja disektor pertanian memiliki pendapatan usaha tani dalam setiap panennya. Pendapatan tiap panen ada yang 2-3 bulan sekali, 3 bulan sekali, 3-4 bulan sekali, dan bahkan ada yang menunggu 6-7 bulan sekali. 
Dari 20 responden tidak semuanya memanen lebih dari 1 jenis tanaman. Dapat dilihat dari Tabel 13 terdapat 1 responden yang berpenghasilan dibawah Rp.500.000 tiap panennya, 16 responden yang berpenghasilan mulai dari Rp.500.000 hingga Rp.1.000.000, 1 responden berpenghasilan Rp.1.000.001 hingga Rp.2.000.000, dan 2 responden lainya berpenghasilan terbanyak yaitu lebih dari Rp.2.000.000. Menurut beberapa responden yang memiliki lahan dan mengolahnya sendiri mengatakan salah satu penyebab tidak ingin menyewa pekerja dikarenakan menghemat biaya karena untuk mengurus kebun juga membutuhkan biaya yang bervariasi sedangkan penghasilan hanya didapat tiap kali panen. Sedangkan pendapatan paling sedikit biasanya adalah mereka yang bekerja sebagai penggarap yang penghasilanya tidak menentu karena penggarap juga tidak selalu mendapat panggilan kerja hanya ada yang tiap bekerja langsung diberi upah dan ada juga yang mendapat upah hanya tiap kali panen. Penghasilan penggarap rata-rata berkisar mulai dari laki-laki 175.000 tiap menggarap lahan dan perempuan sebesar 125.000 .

\section{Biaya Usaha Tani Responden Sebelum Berpindah}

Responden yang memiliki lahan sendiri harus mempunyai biaya usaha tani. Bagi pemilik lahan, besarnya biaya usaha tani juga berpengaruh pada pendapatan serta keuntungan dalam mengelolah hasil pertanianya. Dalam Tabel 14 dapat dilihat biaya usaha tani yang dikeluarkan pemilik lahan dalam mengelolah usaha taninya. Namun tidak semua responden mengeluarkan biaya usaha tani saat bekerja disektor pertanian.

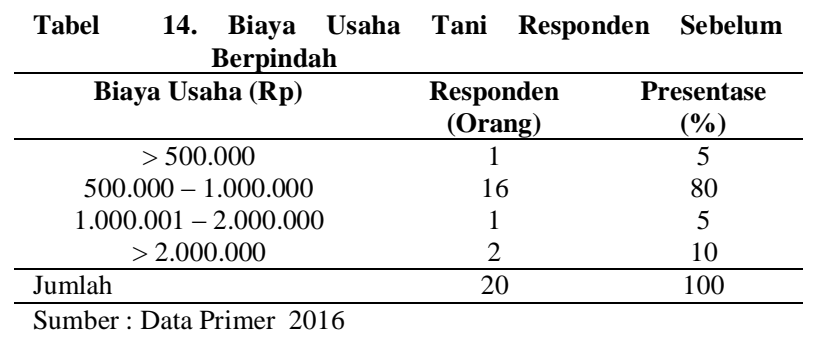

Tabel 14 menunjukan bahwa responden yang memiliki lahan sendiri juga harus mengeluarkan dana untuk mengola usaha taninya. Selain ada yang menyewa pekerja, pemilik lahan juga wajib menegeluarkan biaya untuk usaha taninya. Biaya usaha tani juga digunakan untuk keperluan pengolahan lahan baik untuk membeli peralatan pertanian maupun untuk hal-hal yang dapat membantu terjaganya lahan tersebut. Berdasarkan Tabel 14 terdapat 9 responden yang biaya usaha taninya masih dibawah Rp.500.000, 2 responden sebesar Rp.500.000 sampai dengan Rp.1.000.000, dan 1 responden sebesar Rp.1.000.001 sampai dengan Rp.2.000.000 tidak ada responden yang mengeluarkan biaya usaha taninya lebih dari Rp.2.000.000.

\section{Pendapatan Saat Beralih Pekerjaan}

Upah di sektor pertanian yang tidak menentu membuat responden beralih dari sektor pertanian ke non pertanian keluar dan lebih memilih pekerjaan lainya namun adapula beberapa responden yang tetap menjadikan pekerjaan di sektor pertanian sebagai pekerjaan sampingan. Dengan adanya lahan pertambangan di desa Tatelu membuat responden kebanyakan memilih beralih sebagai penambang karena upahnya lebih jelas dan menguntungkan dibanding bekerja disektor pertanian dengan upah yang tidak menentu. Pendapatan responden dapat dilihat pada Tabel 15.

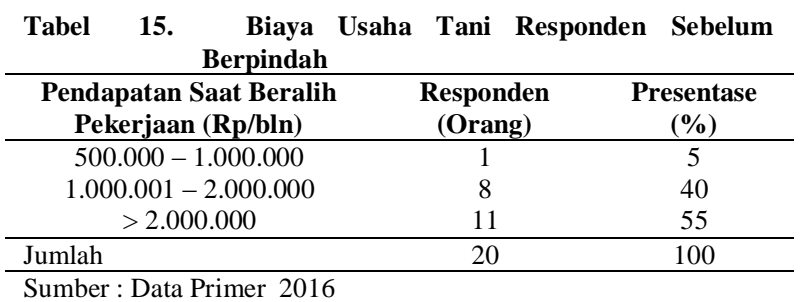

Tabel 15 menunjukan bahwa pendapatan responden setelah beralih dari sektor pertanian ke non pertanian mengalami peningkatan, dimana 1 responden memiliki pendapatan berkisar Rp.500.000 - Rp.1.000.000, 8 responden berpendapatan sebesar Rp.1.000.001 Rp.2.000.000, dan 11 responden lainya memiliki pendapatan lebih dari Rp.2.000.000. Pendapatan saat beralih pekerjaan sangat berpengaruh pada responden dalam memenuhi kebutuhan seharihari, sehingga responden lebih memilih pekerjaan yang menghasikan pendapatan yang cepat untuk mencukupi kebutuhan sehari-hari, dari pada harus menunggu hasil panen yang cukup lama.

\section{Latar Belakang Belakang Sosial Tenaga Kerja yang Berpindah dari Sektor Pertanian ke Sektor Non Pertanian}

Kondisi sosial ekonomi seringkali menjadi gambaran kesejahteraan suatu keluarga dalam masyarakat. Untuk melihat kedudukan sosial ekonomi dapat diketahui dari jenis 
pekerjaan, pola hidup di desa seperti kegiatankegiatan sosial yang diikuti di Desa Tatelu Kecamatan Dimemebe. Dapat dilihat dalam Tabel 16, yang membahas tentang kegiatankegiatan sosial yang diikuti respnden di Desa Tatelu Kecamatan Dimembe.

\begin{tabular}{|c|c|c|}
\hline No. & Kegiatan Sosial & Responden \\
\hline 1. & Rukun Keluarga & 11 \\
\hline 2. & Rukun Duka & 19 \\
\hline 3. & Anggota Lansia & 1 \\
\hline 4. & Rukun Jaga & 12 \\
\hline
\end{tabular}

Tabel 16 menunjukan bahwa lebih dari 1 kegiatan sosial yang diikuti oleh 20 orang responden. Desa Tatelu terdapat bermacammacam kegiatan sosial, mulai dari rukun keluarga dan masih banyak lagi. Dalam mengikuti kegiatan sosial di Desa Tatelu, responden tidak hanya sekedar terlibat dalam kegiatan sosial tersebut namun juga harus mengikuti aturan dalam kegiatan yang telah diikuti, salah satunya dengan menyiapkan uang disaat tertentu (dana tak terduga). Sebagian besar responden yang mengikuti kegiatan sosial di Desa Tatelu seperti rukun dan lain-lain, dikarenakan selain menguntungkan bagi responden juga dapat mempererat tali persaudaraan antar sesama anggota rukun tersebut. Jadi dengan mengikuti rukun di desa, responden harus memiliki pendapatan yang lebih dari cukup dikarenakan harus mengeluarkan dana dalam setiap pertemuan yang selalu diadakan. Itu juga dapat dikatakan sebagai tabungan, karena setiap anggota rukun akan saling bergantian untuk mendapatkannya. Untuk itu sebagian besar responden yang mengikuti rukun di Desa Tatelu Kecamatan Dimembe lebih dari 1 rukun. Dalam Tabel 16 dapat dilihat bahwa terdapat 11 responden yang mengikuti rukun keluarga, 19 responden yang mengikuti rukun duka, 1 responden yang mengikuti anggota lansia, dan 12 responden yang mengikuti rukun jaga.

\section{Faktor-Faktor yang Mendorong Terjadinya Migrasi Tenaga Kerja dari Sektor Pertanian ke Non Pertanian}

Dorongan utama migrasi adalah pertimbangan ekonomi yang rasional terhadap segala keuntungan dan kerugian yang ditimbulkan dalam kegiatan migrasi. Faktor pendorong tersebut merupakan kondisi ril yang terjadi di daerah asal, sehingga seseorang mengambil keputusan untuk melakukan migrasi. Dari hasil penelitian yang telah dilakukan, alasan utama yang mendorong sebagian besar masyarakat di Desa tatelu untuk melakukan migrasi adalah faktor ekonomi maupun faktor non ekonomi. Selain pekerjaan di sektor non pertanian yang lebih menjanjikan ada juga alasan lain responden berpindah seperti halnya usia yang sudah tidak lagi muda sehingga berdampak pada tenanga yang lebih menurun dibanding ketika muda masih lebih bersemangat dalam bekerja di sektor non pertanian. Pendapatan di sektor pertanian yang tidak menentu membuat responden yang berpindah kebanyakan mencari pekerjaan yang selain upahnya lebih menjanjikan juga kesmpatan kerja yang terbuka. Tidak semua responden ketika berpindah pekerjaan kemudian memilih pekerjaan yang membutuhkn keahlian khusus, atau pekerjaan yang harus mempunyai alat-alat pekerja seperti alat trasportasi bagi supir dan ojek ataupun alat-alat untuk penambang dan buruh bangunan, karna ada juga responden yang disebut advonturir yang tidak betah dengan 1 pekerjaan dan selalu ingi mencoba hal-hal baru dalam pekerjaan.

Tabel 16. Kegiatan Sosial yang di ikuti Responden

\begin{tabular}{ccc}
\hline No. & Kegiatan Sosial & Responden \\
\hline 1. & Rukun Keluarga & 11 \\
2. & Rukun Duka & 19 \\
3. & Anggota Lansia & 1 \\
4. & Rukun Jaga & 12 \\
\hline
\end{tabular}

Sumber : Data Primer 2016

Dapat dilihat dari Tabel 17 membahas tentang alasan responden berpindah dari sektor pertanian ke non pertanian. Alasanalasan yang diberikan oleh responden antara lain berkurangnya lahan pertanian 4 responden, upah disektor pertanian pertanian yang rendah 7 responden, faktor usia 1 responden, dan pekerjaan di sektor non pertanian lebih menjanjikan sejumlah 8 responden. Terbukanya peluang atau kesempatan untuk bekerja di sektor non pertanian membuat responden lebih memilih berpindah dari sektor pertanian ke non pertanian, dengan adanya lahan pertambangan di Desa Tatelu Kecamatan Dimembe juga menjadi salah satu daya tarik bagi responden karna kebanyakan responden yang beralih memilih berprofesi sebagai penambang. Selain itu upah di sektor pertanian yang rendah juga membuat responden lebih memilih bekerja di sektor non pertanian atau hanya menjadikan 
pekerjaan di sektor pertanian hanya sebagai pekerjaan sampingan. Selain penambang peluang kesempatan kerja juga terbuka dibidang lain seperti sopir angkot, tukang ojek, buruh bangunan, wirausaha karena untuk bekerja dijenis pekerjaan ini tidak memerlukan syaratsyarat khusus yang terpenting mempunyai keahlian dalam bidang tersebut serta mempunyai alat trasportasi bagi supir angkot dan tukang ojek, dan modal bagi yang berwirausaha. Perkembangan di Desa Tatelu Kecamatan Dimembe juga sangat terlihat dengan adanya pembangunan minimarket seperti indomart dan alvamart dengan peluang kerja bagi mereka yang lulusan SMA, sehingga membuat salah satu responden yang berumur 20 tahun (lulusan SMA) yang telah berpindah pekerjaan lebih memilih bekerja di indomart karna selain tempat bekerja yang nyaman para pekerja juga mendapat upah yang tinggi dan tidak bekerja seharian full dengan upah perbulan yang cukup besar dan hal ini sangat bertolak belakang ketika responden tersebut masi menjadi penggarap yang menurutnya bekerja ditempat yang kurang nyaman karena selain terpapar lansung sinar matahari ketika bekerja siang hari, presponden juga mengatakan upah yang minim dan tidak menentu namun harus bekerja dengan sangat hatihati dan melelahkan. Alassan lain juga yang mempengaruhi responden berpindah pekerjaan di sektor non pertanian yaitu karena responden memiliki keahlian khusus seperti tukang gunting rambut dan dari keahlian khusus inilah responden bisa bekerja di sektor non pertanian.

\section{Harapan Responden yang Berpindah Pekerjaan dari Sektor Pertanian ke Non Pertanian}

Setelah berpindah pekerjaan dari sektor pertanian ke non pertanian, semua responden yang diwawancarai harapanya terwujud ketika berpindah pekerjaan dari sektor pertanian ke non pertanian. Alasan responden berpindah dari sektor pertanian ke non pertanian ada banyak penyebabanya, ada yang dikarenakan berkurangnya lahan yang biasa di alami oleh penggarap, faktor usia, dan pekerjaan di sektor non pertanian lebih menanjikan dibanding di sektor non pertanian dengan upah yg tidak menentu. Upah yang tidak menentu menjadi salah satu alasan responden berpindah namun tidak semua responden yang telah berpindah cukup puas dengan penghasilaan saat ini karena selain adanya penyebab seperti upah yang tidak menentu, ada juga beberapa faktor lainya yang menyebabakan terjadinya perpindahan tenaga kerja dari sektor pertanian ke non pertanian seperti faktor usia dan kurangnya lahan untuk berusaha tani. Namun beberapa responden yang diwawancarai merasa puas dengan hasil yang didapat setelah berpindah dari sektor pertanian ke non pertanian karena selain penghasilan yang didapat cukup besar mereka juga merasa nyaman bekerja di sektor non pertanian.

\section{KESIMPULAN DAN SARAN}

\section{Kesimpulan}

1. Faktor-faktor yang mendorong terjadinya migrasi tenaga kerja dari sektor pertanian ke non pertanian yaitu; berkurangnya lahan pertanian, upah di sektor pertanian yang rendah, faktor usia, dan pekerjaan di sektor non pertanian lebih menjanjikan.

2. Sebagian besar responden yang mengikuti kegiatan sosial di Desa Tatelu seperti rukun dikarenakan selain menguntungkan bagi responden juga dapat mempererat tali persaudaraan antar sesama anggota rukun tersebut. Dengan mengikuti rukun di desa, responden harus memiliki pendapatan yang lebih dikarenakan harus mengeluarkan dana dalam setiap pertemuan yang selalu diadakan.

3. Setelah berpindah pekerjaan dari sektor pertanian ke non pertanian, semua harapan responden yang diwawancarai terwujud karena selain penghasilan yang didapat cukup besar mereka juga merasa nyaman bekerja di sektor non pertania

\section{Saran}

1. Sebaiknya tenaga kerja yang telah bermigrasi mencari pekerjaan di sektor non pertanian yang lebih menguntungkan dan jika memungkinkan tetap menjadikan pekerjaan di sektor pertanian sebagai pekerjaan sampingan agar pendapatan lebih besar

2. Tenaga kerja yang bermigrasi memiliki latar belakang yang berbeda-beda sehingga dalam memilih pekerjaan harusnya disesuaikan dengan kondisi latar belakang tenaga kerja.

3. Setelah berpindah sebagian besar harapan responden terwujud untuk kedepannya pemerintah harus terus berinovasi agar pekerjaan di sektor pertanian dan non pertanian tetap saling menguntungkan bagi kemajuan desa Tatelu Kecamatan Dimembe. 


\section{DAFTAR PUSTAKA}

Ediyana I.W. 2006. Struktur Ekonomi dan Kesempatan Kerja Sektor Pertanian dan Non Pertanian Serta Kualitas Sumberdaya Manusia di Indonesia. Ilmu Ekonomi Pertanian. Bogor.

Umami E. 2010. Dampak Migrasi Terhadap Kondisi Sosial Ekonomi Masyarakat. Malang.

Hardono G dan Pranandji Tri. 2015. Dinamika Penyerapan Tenaga Kerja Pertanian. Jakarta.

Pesik C.S. 2016. Faktor-Faktor Penyebab Pergeseran Tenaga Kerja dari Sektor Pertanian ke Non-pertanian. Manado: Universitas Sam Ratulangi.

Ratnaningsih E.S. 2013. Pengaruh Pertumbuhan Sektor Industri Terhadap Penyerapan Tenaga Kerja di Kota Surabaya. Jurnal Universitas Negeri Surabaya.

Rompas J., Engka D., \& Tolosang K. 2015. Potensi Sektor Pertanian dan Pengaruhnya Terhadap Penyerapan Tenaga Kerja di Kabupaten Minahasa Selatan. Jurnal Berkala Ilmiah Efisiensi. Vol. 15, No. 4, Hal. 124 - 136.

Sagir S. 1996. Kesiapan Agroindustri Menjelang Era Globalisasi Perdagangan Bebas, AFTA 2003 dan APEC 2002. Makalah Pembanding Forum Komunikasi Agribisnis Bidang Ekonomi Pada Seminar Tanggapan Pendidikan Tinggi Dalam Bidang Agroindustri Menghadapi Era Pasar Bebas, Cisarua Bogor, Desember 1996, Bogor.
Satria A. 2016. Sektor-Sektor Produksi Dalam Ekonomi. http:// www.materibelajar.id/2016/07/sektorsektor-produksi-dalam ekonomi. 02 Desember 2016.

Sinuraya J dan Saptana. 2007. Migrasi Tenaga Kerja Perdesaan dan Pola Pemanfaatannya. Jurnal SOCA 7(3).

Sugiyono. 2012. "Memahami Penelitian Kualitatif". Bandung : ALFABETA.

Sukanto D.G.T. 2010. Analisis Peranan Sektor Pertanian Terhadap Perekonomian Jawa Tengah (Pendekatan Analisis Input - Output). Semarang: Universitas Diponegoro.

Sumanto A. 2009. Identifikasi Faktor- Faktor Sosial- Ekonomi Migrasi Tenaga Kerja (Kasus Ibu Rumah Tangga yang Bekerja dari Sektor Pertanian ke Sektor Non- Pertanian). JESP Vol. 1, No. 2.

Tambunan T.H. 1996. Perekonomian Indonesia. P.T. Gahlian, Jakarta.

Tirtosudarmo R. 1993. Migrasi dan Perubahan Sosial di Masa Orde Baru. Analisis CSIS. Jakarta.

Suhaji M.T. 2004. Faktor - Faktor yang Mempengaruhi Kepuasan Kerja (Studi pada Karyawan Sekolah Tinggi Ilmu Farmasi"YAYASAN PHARMASI" semarang). Semarang. 